\title{
The Role of Locus of Control, Meaning of Life and Marital Relationships in Predicting Quality of Life
}

\author{
Moatamedi $\mathrm{A}^{* 1}$, Aazami $\mathrm{Y}^{2}$, Jalalvand $\mathrm{M}^{3}$, Mehrad Sader $\mathrm{M}^{4}$
}

\begin{abstract}
Introduction and purpose: In the process of development, retirement is a stage of beginning for important potential changes in life and this stage effect on quality life of the retirements. So, present study with the aim of investigating prediction of quality of life through locus of control, meaning of life and marital relationships was performed on retirements of Nahanavand of Iran.
\end{abstract}

Materials and methods: This is a survey study and from correlational type. The population of the present study were all the retirements of Nahavand which based on previous literature 200 of them were selected through random sampling as study sample. Tools were Rotter's Locus of Control Scale (RLCS), Meaning of Life Questionnaire (MLQ), Marital Status Inventory and WHO Quality of Life (WHOQOL-26). Data were analyzed through correlation coefficient and stepwise multiple regression.

Findings: The results of the study showed significant relationship between dependent and independent variables including: a positive weak relation between locus of control and quality of life, a positive medium relation between search for meaning and quality of life, a positive pretty strong relation between presence of meaning and quality of life and finally a negative pretty strong relation between marital status and quality of life. In addition, the results of regression analysis showed that presence of meaning can predict quality of life positively and marital status which higher scores in it means more disruptions in marital relationship, can predicts quality of life negatively and the other independent variables were excluded because of low Beta coefficients.

conclusion: Based on study results it could be said that individuals with internal control, feeling purposeful in life and more marital satisfaction can deal with retirement better than others and even they can experience a successful retirement which results in experience higher levels of quality of life.

Keywords: Locus of Control, Meaning of Life, Marital Relationships, Quality of Life, Retirement

Copyright () 2018 Quarterly Journal of Geriatric Nursing.This is an open-access article distributed under the terms of the Creative Commons Attribution international 4.0 International License(http://creativecommons.org/licenses/by /4.0/) which permits copy and redistribute the material, in any medium or format, provided the original work is properly cited.

1. Associate Professor of Psychology, Department of Clinical Psychology, Faculty of Psychology and Educational Sciences, Allameh Tabataba'i University, Tehran, Iran

(Corresponding Author):E-mail: a_moatamedy@yahoo.com)

2. PhD student in Psychology, Department of Clinical Psychology, Faculty of Psychology and Educational Sciences, Allameh Tabataba'i University, Tehran, Iran

3. Master of Clinical Psychology, lecturer of Afarinesh Nonprofit University of Boroujerd, Lorestan, Iran

4. PhD student in Psychology, Department of Clinical Psychology, Faculty of Psychology and Educational Sciences, Allameh Tabataba'i University, Tehran, Iran 


\title{
نقش منبع كنترل، معناى زندكَ و روابط زناشويى در ييشبينى كيفيت زندكى بازنشستخًان
}

\author{
عبدالله معتمدى" '، يوسف اعظمى '، محمد جلالوندّ، محمد مهر اد صدرع
}

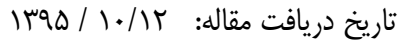

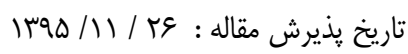

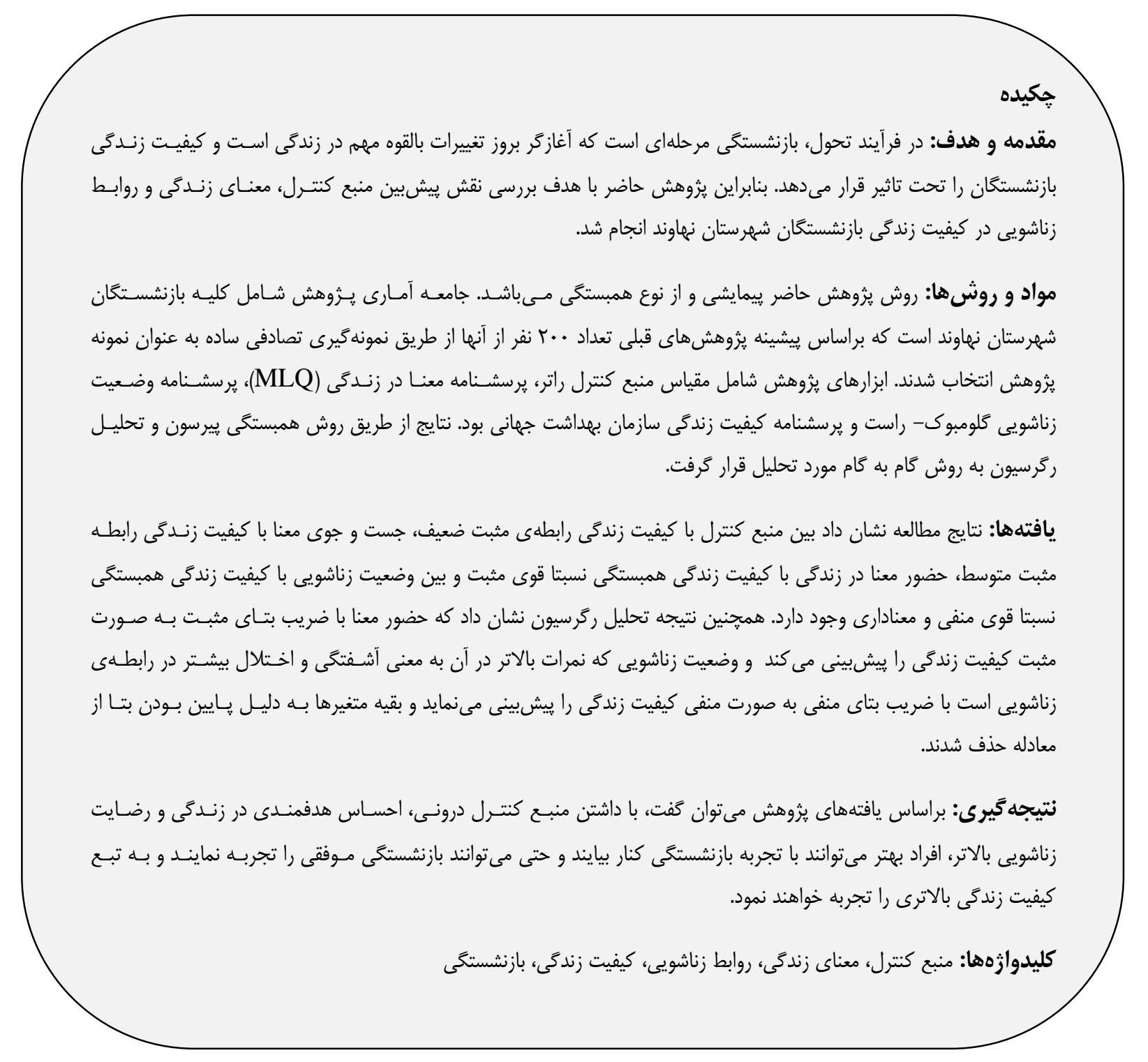

ا. دانشيار روانشناسى، كروه روانشناسى بالينى، دانشكده روانشناسى و علوم تربيتى دانشخاه علامه طباطبائى، تهران، ايران

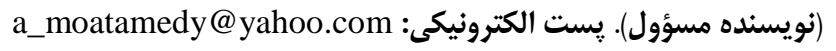

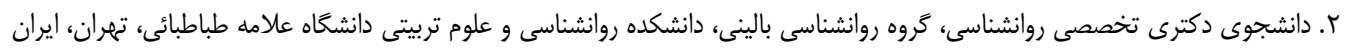

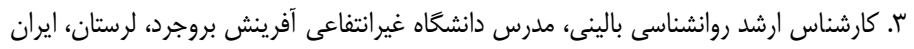

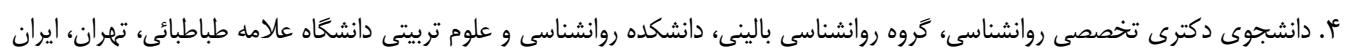


سازمان بهداشت جهانى تعريف جامعى از كيفيـت زنـدگى ارائـه نموده است كه عبارت است از درك افراد از وضعيت زنـدگى در قالب فرهنَ و ارزشهاى حاكم بر جامعه و در راستاى اهـداف،

$$
\text { استانداردها و علايق افراد مىباشد [ع]. }
$$

همجنين فاسينو در تعريف خود اظهـار مسىدارد امـروزه كيفيـت زندكَى يك شاخص اساسى محسـوب مـىشـود و از آنجـا كـهـ

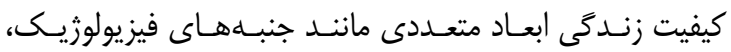
عملكرد و وجود فرد را در بر مسى گيـرد توجـهـ بــهـ آن از اهميـت خاصى برخوردار بوده و براى ارزيابى صـحيح آن بايسـ بــه ابعـاد

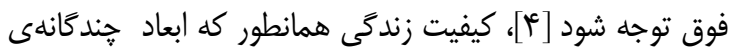
عملكرد جسمى، روانى و اجتماعى فرد را در بر مى گيرد از عوامل مختلفى هم تاثير مىيذيرد [ه]. يكى از اين عوامل منبع كنتـرل افراد مىباشد [V]]. منبع كنترل يكى از مولفـهــاى شخصـيتى است كه در خارجوب نظريه راتر (1909) ارايه شده است. راتر دو نوع منبع كنترل را بيان مسى كنــ يكى منبـع كنتـرل درونسى و ديخًرى منبع كنترل بيرونسى اسـت. افـرادى كـهـ موفقيـتهـا و شكستهاى خود را عموما به شخص خود (كوشش يـا توانسايى شخص) نسبت مىدهند، داراى منبع كنترل درونى ناميده مسشوند و در مقابل افرادى كه موفقيتها و شكستهاى خود را به عوامل خارج از خود (مثل شانس، دشوارى موقعيت) نسبت مىدهند، داراى منبع كنتـرل بيرونسى هسـتند [1]. حس كنتـرل و كيفيت زندگَى براى افراد با هم همبستخى درونسى دارنسـ. حس كنترل يك عامل محورى در گسترهاى از رفتارها شامل عملكرد هوشى و مقابله با استرس و هم بهزيستى جسمى و روانى، مىباشد كه عناصر ضرورى كيفيت زندگى هستند. افراد مسىتوانتـد حس پايــارى از خـود را عليـرغم تغييـرات آرام و تــدريجى در
بازنشستخى يديده يِيجيدهاى است كه شامل جنبههـاى رويـهاى مرتبط با آمادگى براى بازنشستخى است و كاهى، با جنبـههـاى خاصى مثل تصميم براى بازنشستخى در اينجا و اكنـون مـرتبط است. اگرجه بازنشستخى مكررا بــه عنـوان خرتخــاه (سراشـيبى) انتقال از شاغل بودن در يك لحظه به توقف كامل فعاليت شغلى در لحظه بعدى است، امـا شـواهد نشـان مسىدهـــ كـهـ پيديـده بازنشستخىى، انتقال قييجيـدهتر و تـدريجى تـرى اسـت [1]. در فرايند تحول، بازنشستخى مرحله است كه آغازگر بروز تغييـرات بالقوه مهم در سلامت، اقتصاد، و فعاليتهاى خانه، جامعه و كـار است. تعجبآور نيست كه در دهه اخير افزايشى در يـرُوهش در ارتباط با هم مسـائل فـردى و هـمم اجتمـاعى در بازنشسـتخى و انتقـال بازنشسـتخى مشـاهده شــده اسـت [r]. در يـك جامعــه سالمند، انتقـال موفـق از كـار بــه بازنشسـتخى و دسـتيابى بــه سازگًارى بازنشستخى با كيفيت خـوب، مسـائل عمـدهاى بـراى افراد، سازمانها و دولتها مــباشــــ[ب]. بازنشسـتخى كـهـ بــه معناى جدا شدن فرد از نقشـى اسـت كـه سـالهــاى متمـادى تصدى آن را داشته است و اكنون در قالب جديدى در آمده است [ז]، يكى از رويدادهاى مهرم در دوران سالمندى است كه مـىتواند كيفيت زندگى فرد را تحت تاثير خـود قـرار دهـــ [ه]، بـــ طورى كه وقتى فرد وارد مرحله بازنشستخى مىشـود بــه دليـل جدا شدن از شغل و از دسـت دادن قابليـتهـــ قبلى، و عـدم آشنايى با نقش جديد دجار اضطراب شده و ايسن امـر مسىتوانـــ روى ابعاد مختلف جسمى، روانى و در نهايت كيفيت زندگى فرد

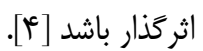


زندگى را با فعاليتهاى مـذهبى، علـل اجتمـاعى، و ارزشهـاى سنتى و فرهنكى به طور مرتبطتـر و نزديـكتــى ادراك كنـــــ [با]]. منابع معناى كه بـا ارزشهـاى انسـانى و اخلاقى، علـل اجتماعى، و امنيت مالى ارتباط دارند براى سالمندان در مقايسـهـ با جوانان از اهميت بيشترى برخودار هستند [سI]]. يزوهشها نشان داده است كه معناى زندگى به طـور مثبتس بـا بجزيستى روانشناختى و ذهنى، كيفيـت زنـــىى، خـوشبينسى و

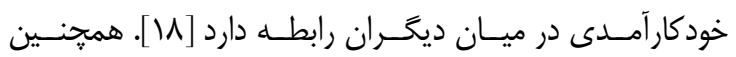
مطالعات نشان داده است كه معناى زندگى نقش ميانجى را در رابطه بين خاطرهيردازى منفى و يريشانى روانشـناختى در ميـان سالمندان مبتلا به افسردگى خفيف تا متوسط ايفا مى كنــ [19]. جستجو بـراى معنـا اصـولاً در بـافتى از پاسـخ بـهـ رويـدادهاى استرسزاى منفى مانند تغييراتى در بافت كـارى، از دسـت دادن آشنايان و مشكلات زناشويى مـورد بررسـى قـرار گرفتـه اسـت

عامل سومى كه مىتواند كيفيت زندَى افراد را تحت تاثير قـرار دهد، كيفيت روابط زناشـويى زوجـين اسـت [•r]. بازنشستـى اغلب با تغييرات عمدهاى در زندگى زوجين سالمند همراه اسـت كه دامنهاى از ترى خانه توسط فرزندان تا بازتعريف نقشهـاى زوجين رادر برمى گيرد [ [r]. كيفيت روابط زناشويى بـه عنـوان ميزان توافق نسبى زن و شوهر درباره موضوعات مهمى جـون

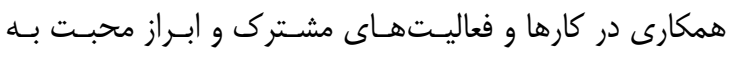
يكديخر تعريف شده است [Tr]. مرور بيشينه در ارتباط با زوجين سالمند دو سناريو احتمالى را در سير تكاملى كاركرد زناشويى در طول عمر روشن ساخته است. براسـاس سـناريوى اول، هـر دو زوج كاركرد و رضايت زناشويى خوبى در اوايل رابطهاشان دارنـــ و سبس با ورود (تولد) فرزندان و همراه با تعهدات بسـيارى كـه

خودشان و محيط اجتماعىاشان كه همراه سالمندى است، حفظ كنند [V]. در واقع كنترل داشتن بر زندگى خود آثار سـودمندى دارد و سبب سازكارى روانشـناختى بيشـتر و كـاهش مشـكلات جسمى، روانى و رفتارى مىشود [9]، همجنين برخى مطالعات هم نشان دادهاند كه افرادى كه داراى منبع كنترل درونى هستند بيش از افرادى كه منبع كنترل بيرونى دارند، از زندگى مشـترى احساس رضايت مى كنند [•1-11]. يكى ديكًر از متغيرهايى كه مىتواند كيفيت زندَّى بازنشستكان

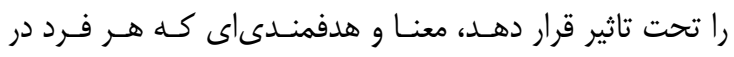
زندگى دارد، مى باشد. مفهوم معناى زندگى (MIL) يـك سـازه مهم براى بهزيستى انسانى اسـت كـه وازه جديـدى نيسـت. در

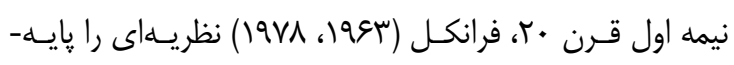
كذارى كرد كه موكداً اين مفهوم را به عنـوان داشـتن حسـى از معنا تعريف نمود كه براى انسان هم يكى عامل بازدارنده و هـم محافظت كننده از رنـج وجـودى اسـت. از كـار اوليـه فرانكـل، نويسندكان ديكَرى هم به فهم و روشــسـازى مفهـوم معنـاى

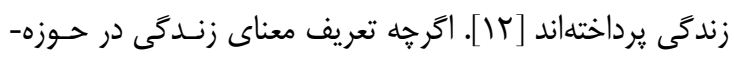
هاى مختلف متفاوت است اما اين مفهوم به طور گسترداى بــه عنوان يك عنصر مهم كاركرد روانشناسى مثبـتنعــر يذيرفتـهـ شده است [سا]. دهها يزوهش شواهدى را فراهم كردهانـد كـهـ. نشان مى دهند معناى زندكى و بحـــان در زنــدَى بـر سـامت

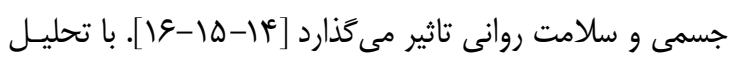
منابع معنا از طريق يك ديـدكاه تحــولى، برخـى از نويسـندكًان مدعى هستند كه آنها در طى عمر تغيير مى كنند به اين علت كه

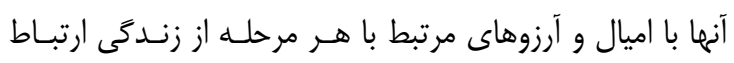
دارند [IV]. شواهد تجربى با هدف ارزيـابى رابطـهـ بـين سـن و منابع معنا دريافتهاند كه افراد مسنتر حَرايش دارنــــــا معنــاى 
رابطه مستقيمى وجود دارد [عَr]. بنابراين روابـط زناشـويى هـم مىتواند كيفيت زندگى را تحت تاثير قرار دهد.

براساس آنجه كَفته شد مىتوان كَت كه با توجه به آمار بـالاى افرادى كه هر سال بازنشسته مىشوند از يك سوى، و مسائل و مشكلاتى كه در ابعاد مختلف به ويزه در بعـد روانشــاختى، كـهـ اين افراد با آنما مواجه مىشوند، اين ڤيديده انتقالى را در زنـدگى

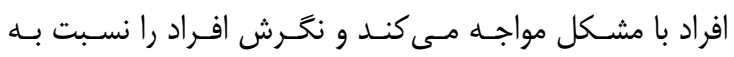
بازنشستخى به عنوان پيديدهاى استرسزا و منفى تحت تاثير قرار مىدهد كه اين مسئله به تبع بـر كيفيـت زنـدكى بازنشسـتكان تاثير مى گذارد. اما براساس مطالعات صورت گرفته عواملى مسىتوانند به طور مستقيم و غيرمستقيم كيفيت زندگى افراد را تحت تاثير قرار دهند كه از جمله آنها مىتـوان منبـع كنتـرل فـردى، معناى فرد از زندگى و كيفيت روابط زناشويى افراد را نام برد. هر جند اين عوامل ممكن است در ساير گروههـاى جمعيتـى مـورد بررسى قرار گرفته باشد اما براساس مطالعات انجام گرفته، ايـن عوامل به ويزه تركيب آنها با هم در بازنشستخان بررسى نشــه است. بنابراين يثوهش حاضر با هدف بررسى نقش منبع كنترل، معناى زندگى و روابط زناشويى در يـيشبينسى كيفيـت زنـدگى

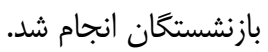

\section{مواد و روش ها}

يزوهش حاضر يِيمايشى از نوع همبستخى مىباشد، كه در آن به بررسى نقش منبع كنترل، معناى زنسدگى و روابـط زناشـويى در كيفيت زندگى بازنشستخان يرداخته شده است.

جامعه آمارى يثوهش شامل كليه بازنشستخان شهرستان نهاوند است كه تعداد +. ب نفر از آنها به عنوان نمونه يزوهش انتخـاب شدند. با توجه به اينكه يكى از روشهاى تعيـين حجـم نمونـه،
مشخصه اين دوره است، رضايت زناشويى كاهش مىيابد. با اين وجود، اين دوره زودكَّر است، هرا كه روابـط زناشـويى در طـى دوره بازنشستخى به دليـل اسـترس خـانوادگى و شـغلى كمتـر، بهبود مىيابد. اين سناريو به عنوان يـك 》مـاه عسـل ثانويـهـه توصــيف شــده اسـت [بr-זَr]. در مقابــل، ســناريوى دوم بازنشسـتخى را بــه عـــوان يـك دوره انتقـالى مشـكل زا بـراى سالمندان توصيف كرده است. ساز گارىهــاى معينـى كـهـ بـراى مديريت تغييرات طبيعى اين دوره شامل كـاهش درآمـد، تـرى خانه توسط فرزندان، صرف زمان بيشتر با همديخر، برنامهريـزى براى فعاليتهاى مشترى و بازنشستخى از فعاليتهاى حرفهاى، در اين دوره مشكل آفرين هستند. تمام اين عوامـل تنهـا منـابع استرسزايى نيستند كه سالمندان بايد با آن سازگًار شوند، بلكـهـ همجنين كاركرد زناشويى و تشديد مسائلى كـهـ قبـال در رابطـهـ وجود داشته است را هم به صورت موقت و هم دائم، تحت تاثير قرار مىدهد [fr]. لذا مشكلاتى كه بازنشستگًان در اين دوره با آن مواجه مى شوند بر كيفيت روابط زناشويى و بـهـ تبـع كيفيـت زندگى آنها تاثير مى گـذارد. نتيجــه مطالعـه تـرودل و همكـاران نشان داده است كـهـ زوجـين سـالمند سـطح خـوبى از كـاركرد زناشـويى و سـطح يـايينى از يريشـانى روانشــاختى دارنسـد. امـا عليرغم درصد متوسطى كاركرد زناشويى مثبت، نسبت معنادارى از سالمندان يريشـانى زناشـويى جــى را تجربـه كردنــ [ [T]. مطالعات نشان داده است كه كيفيت روابط زناشويى با تعدادى از قيامدهاى روانشناختى مانتــد احسـاس خوشـبختى و رضـايت از زندكَى، رضايتمندى زناشويى، ارزش خـود و اعتمـاد بـه نفـس، افزايش كيفيت زندگى و حمايت اجتماعى ادراك شده در زوجين رابطه دارد [rQ [T]. همجنين نتايج يُوهش رحيمى و خير نشان داد كه بين الخوهاى ارتباطى و زناشويى خـانواده و كيفيـت زنـدگى 
دو جمله به صورت (A) و (B) مى باشـد، كـه در يكى مقيـاس كنترل درونى و در ديخرى مقياس كنترل بيرونى قـرار دارد، و \& مورد از وج مورد خنثى مىباشد كه بـراى ثوشـيده نخـهـ داشـتن هدف يرسشنامه از آزمودنى به كار برده شده است. نمـرهــارى اين آزمون با شمارش ياسخهاى كنترل درونسى و بيرونى از سب مورد بدست مىآيد. نمره 9 يا بالاتر نشانه منبع كنترل بيرونى، و نمره كمتر از 9 نشانه منبع كنترل درونى است. روايسى و پايـايى يرسشنامه در يثوهش فياض، كاظمى، رئيسون و محمدى مـورد تاييد قرار كرفته است و يايايى مقياس بـا روش ضـريب آلفـاى

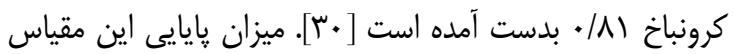
در يثوهش حاضر با استفاده از روش آلفاى كرونباخ VY/ • بدست

ץ. يرسشنامه معنا در زنــدَى (MLQ): ايـن مقيـاس

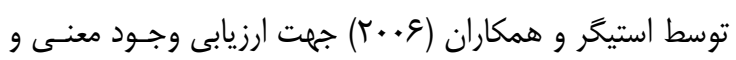
1. تلاش براى يافتن آن ارائه شده است. ايـن مقيـاس شـامل گويه است و دو زير مقياس وجود معنـى در زنـدگى و جسـتوجو براى يافتن معنى را ارزيابى مى كند. يايـايى آزمـون و بازآزمـايى اين مقياس در ايران با دو هفته فاصله براى زير مقيـاس وجـود

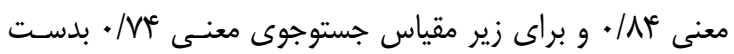
آمد [اسّ]. ميزان گايايى اين مقياس در يزوهش حاضر با استفاده از روش آلفاى كرونباخ در زير مقياس جسـوجوى معنـا هـ/• و در زير مقياس وجود معنا • • • بدست آمد. ". يرسشنامه وضعيت زناشويى كَلومبـوك- راسـت

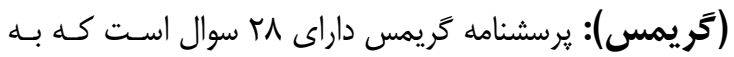

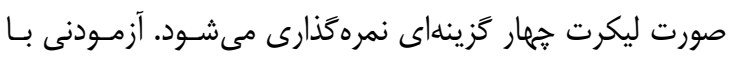
توجه به وضعيت زناشويى خود، يكى از جهار ززينـه را انتخـاب
محاسبه ميانخين حجم نمونه سه يزوهشى اسـت كـه در زمينـه موضوع مورد يزوهش انجام شده اسـت [TV]، لـذا در يـرّوهش حاضر جهت برآورد حجم نمونه از اين روش استفاده گرديد. اين سه يزوهش عبارت بودند از: مطالعـه محققى، سـجادى، زارع و

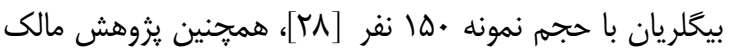
و همكاران با نمونهاى برابر ·. . نفر [ع]، و يـروهش سـليمى، دشت بزرگىى، مظفرى و تابش كه در آن نمونه اى معـادل • نفر مورد بررسى قرار گرفتـه اسـت [جr]. بـا محاسـبه ميـانگگين حجم نمونه اين س يثوهش، اين تعداد برابر lNV نفر بدست آمــ و لذا به خاطر احتمال ريزش نمونه و عدم تكميل يرسشـنامههـا تعداد . . r يرسشنامه توزيع گرديد. روش نمونه گيرى در بزوهش حاضر روش تصادفى ساده بود.

ملاكهاى ورود و خروج از يثوهش: افـرادى كـه حـداقل يـى سال از بازنشستخى آنها كذشته باشد، از لحاظ جسمى يـا روانى به بيمارى يا اختلال خاصى مبتلا نباشند، از لحاظ بينايى مشكل خاصى جهت تكميل يرسشنامههاى يـرُوهش نداشـته باشـند، از توانايى شنوايى لازم جهت توجيه شركت در يـروهش و كسب رضايت آكاهانه جهت تكميل ابزارهاى يزوهش برخوردار باشند.

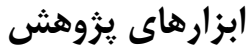
ا. مقياس منبع كنتــرل راتــر: ايـن مقيـاس توسـط راتـر (عو19) ساخته شده است و ادراك فرد را از منبع كنترل رفتـار و ييامدهاى حوادث زندگى شخصى مورد سنجش قـرار مسىدهـد. نمرهذارى به اين صورت است كه اخر آزمودنى به جملهاى كـه منبع كنترل را مىسنجد ياسخ دهد، نمره (صفر يا يك) مى گيرد. اين مقياس داراى وج مورد است كه هر مـورد از مقيـاس داراى 
ترجمه شد. استانداردسازى، ترجمه و هنجاريابى نسخهى ايرانى اين يرسشـنامه توسـط نجـات، منتظــى هلاكويى، محمـــ و مجدزاده صورت كَرفت كه مقدار آلفاى كرونباخ در تمام حيطه-

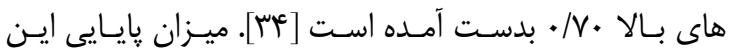
مقياس در يزوهش حاضـر بـا اسـتفاده از روش آلفـاى كرونبـاخ

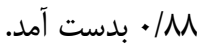

فرايند اجراى يزوهش و روش تجزيه و تحليل دادهها:

انتخاب نمونه بدين صورت بود كه ابتدا پِ از كسـب مجـوز از دانشخاه به سازمان ها و ادارات شهرستان نهاوند مراجعه شد و از مسئولين سازمانها جهت همكارى بـا يزوهشــَران درخواسـت

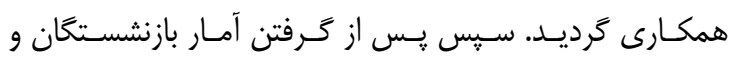
انتخاب تصادفى از روى ليست با افراد نمونه تماس كرفته شد و پِ از توجيه آنها براى شـركت در يـروهش از آنهـا درخواسـت همكارى كَرديد. در مرحله بعد بِ كسب رضـايت آكاهانهـ بـهـ صورت شفاهى و كتبى از آنها، در مـورد مراجعه حضـورى يـا غيرحضورى جهت شركت در يزوهش از آنها نظرخواهى كرديـــ. سبس افرادى كه تمايل به مراجعه حضورى داشتند با مراجعه به اداره يا سازمان محل خدمت شهرستان، ابزارهـاى يـروهش را تكميل نمودند و ساير افرادى كه به هر دليلى قـادر بـه مراجــهـ حضورى نبودند، يرسشنامههـا از طريـق ڤِسـت بـهـ آدرس آنهـا

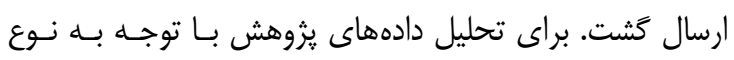
روش يزوهش، از روش همبستخى ييرسون و تحليل ركرسـيون كام به كام استفاده كرديد.
مى كند. اين يرسشنامه توسط راسـت، بـــون، كـراو و همكـاران (1991) ساخته شده و براى ارزيابى روابط زناشويى به كار مسىرود. از لحاظ روايى اين يرسشنامه با نظريه فينجــام و برادبـورى در مورد كيفيت زندگى زناشويى همسو اسـت [بس]. در يـروهش عيسىنزاد، احمدى و اعتمادى بِايايى اين برسشـنامه بـه شـيوه

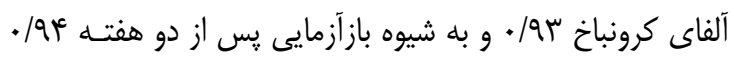
كزارش كرده است [بץ]. در يـروهش ســيف الـدينى بنـادكوكى ״يايايى يرسشنامه با روش آلفاى كرونباخ MM/• بدست آمد [بس]. ميزان پايايى اين مقياس در يُوهش حاضر بـا استفاده از روش آلفاى كرونباخ • • • - بدست آمد.

\section{ع. يرسشــنامه كيفيـت زنــدكى ســازمان بهداشـــ} جهانى فرم حr ســوالى (WHOQOL-26): در ايـن يزوهش از فـرم كوتـاه عب سـوالى برسشــامه كيفيـت زنـدكى سازمان بهداشت جهانى استفاده گَرديده اسـت. ايـن فـرم داراى عب سوال ه كزينهاى است و نمرهذارى آنها به صورت ليكـرت بين ا (اصلا) تا ه (خيلى زياد) اسـت. لازم بـه ذكـر اسـت كـه سوالات سّ، ז و צr به صورت منفى نمرهذارى مىشـوند. ايـن يرسشنامه داراى ؟ بعد سـلامت جسـمانى، روانس، اجتمـاعى و محيط فيزيكى مىباشد كه به عنوان يك مقيـاس جـامع مـورد استفاده قرار مى گيرد و در مجموع شامل كيفيت زنـدَى كلى و سطوح سلامت عمومى باشد. از سال ع991، اعتبار و پايايى اين يرسشنامه توسط سازمان بهداشت جهانى در كشورها و فرهنگهاى مختلف مورد بررسى قرار گرفتـه اسـت، و در سـال ....، اين برسشنامه به طور همزمان در ال كشـور جهان طراحسى و 
يافتهها

در جدول شماره ا معيارهاى يراكندگى سنى ارائه شده است.

جدول (. معيارهاي سنى و جمعيتى

زن

مرد

متغيرهاى يزوهش

\begin{tabular}{|c|c|c|c|c|}
\hline انحراف معيار & ميانگين & انحراف معيار & ميانغين & \\
\hline$\Delta / \Delta \Lambda$ & $\Delta S / \Delta$ & 81.9 & $\Delta V / 19$ & سن \\
\hline ( & $0 \cdot / F^{c}$ & r & $01 / 19$ & سن بازنشستخى \\
\hline$\Delta / \cdot \cdot$ & $r / \wedge \Delta$ & s/l & $\Delta / T V$ & سابقهى مديريت \\
\hline $1 / .0$ & $r / r q$ & $1 / \% F$ & $r / r f$ & تعداد فرزندان \\
\hline
\end{tabular}

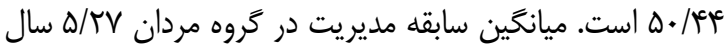
نتايج جدول ا نشان مى دهد ميانگين و انحراف استاندارد سـنى و در گروه زنان هم مردان (\&/\&/9 ميانگَين سن بازنشستخى در گروه مردان 1/19 ه و در گروه زنان

در جدول r اطلاعات جمعيتشناختى گروه نمونه شامل شغل، تحصيلات، وضعيت تاهل و سابقه تغيير شغل ذكر شده است. جدول r. ويزَّى هاى جمعيتشناختى تَروه نمونه

\begin{tabular}{|c|c|c|c|c|c|}
\hline \multicolumn{2}{|c|}{ زن } & \multicolumn{2}{|c|}{ مرد } & \multirow{2}{*}{\multicolumn{2}{|c|}{ ويزگَى هاى دمو كَرافيك }} \\
\hline درصد & تعداد & درصد & تعداد & & \\
\hline$\% v \cdot / 8$ & MF & $\%+4 / 1$ & is & معلم & شغل \\
\hline$\% r \varepsilon / \Delta$ & 9 & $\%$ \% & $r$. & يرسنل بهداشت & \\
\hline$\%$ & • & $\% \mathrm{~N} / \Lambda$ & MI & بيمه و بانك & \\
\hline$\%$ & . & $\% s / r$ & $\checkmark$ & فرماندارى و شهردارى & \\
\hline$\% r / q$ & 1 & $\% \mathrm{~V} / \mathrm{I}$ & $\wedge$ & ساير & \\
\hline$\%$ & . & $\% 1 \cdot / v$ & $\pi$ & زير دييله & تحصيلات \\
\hline$\%+4 / 1$ & 10 & $\% r \cdot / 4$ & me & دييلم & \\
\hline$\% \Delta \Delta / q$ & 19 & $\% \Delta \mu / q$ & 9. & كارشناسى & \\
\hline$\%$ & $\cdot$ & $\% \Delta / \kappa^{c}$ & 8 & كارشناسى ارشد & \\
\hline$\% 1 \ldots$ & re & $\% 99 / 1$ & 111 & متاهل & وضعيت تاهل \\
\hline$\%$ & . & $\% \cdot / 9$ & 1 & مطلقه & \\
\hline$\%$ & . & $\% 1 \cdot / v$ & ir & بله & سابقه تغيير شغل \\
\hline$\% 1 \ldots$ & Mr & $\% \wedge 9 / \mu$ & $1 \ldots$ & خير & \\
\hline
\end{tabular}

وضعيت تاهل هم عمدتا متاهل بودهانــد. ضـمنا برخـى از افـراد گروه نمونه اطالاعاتى را در برخى از موارد گزارش نكردهاند.
نتايج جدول r هم نشان مىدهــد از لحــاظ شـنلى بيشـتر افـراد نمونه معلمين و يرسنل بهـاشت بودهانـد، از لحـاظ تحصـيلات

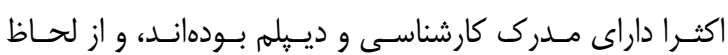


ميانكَين و انحراف معيار متغيرهاى مطالعه نيز در جدول ب ارائه شده است.

جدول س. ميانگين و انحراف معيار متغيرهاى يزوهش براى زنان و مردان

\begin{tabular}{|c|c|c|c|c|}
\hline \multicolumn{2}{|c|}{ 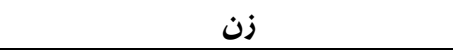 } & \multicolumn{2}{|c|}{ مرد } & \multirow[t]{2}{*}{ متغيرهاى يزوهش } \\
\hline انحراف معيار & ميانگَين & انحراف معيار & ميانغين & \\
\hline T/Kr & $\mid r / \cdot \Delta$ & T/צT & $11 / \pi 1$ & منبع كنترل \\
\hline $4 / 89$ & $r \cdot / r \varepsilon$ & $r / \Lambda \mu$ & TN/A. & جست و جو براى معنا \\
\hline$f / v q$ & 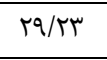 & $F / T I$ & $r 9 / \mathrm{r}$ & حضور معنا \\
\hline 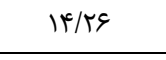 & $\Delta \& / \cdot \Lambda$ & $11 / 19$ & $\Delta \Delta / r \cdot$ & وضعيت زناشويى \\
\hline $1 / \mathrm{v}$ & V/OT & $1 / 4 \Delta$ & $V / D)^{C}$ & كيفيت زندكى \\
\hline
\end{tabular}

براى بدست آوردن رابطهى همبستخى بين متغيرهاى مطالعه از ضريب همبستىى ييرسون در سطح ه+/ استفاده شد. نتايج در جدول شماره f نشان داده شده است .

جدول f أ ماتريس ضرايب همبستخى ييرسون ميان متغيرهاى يزوهش

\begin{tabular}{|c|c|c|c|c|c|}
\hline كيفيت زندگى & وضعيت زناشويى & حضور معنا & جست و جوى معنا & منبع كنترل & متغير ها \\
\hline & & & & 1 & منبع كنترل \\
\hline & & & 1 & $-\cdot / \cdot r$ & جست و جوى معنا \\
\hline & & 1 & $\cdot 19$. & $.1 . e^{c}$ & حضور معنا \\
\hline & 1 & $-\cdot / 4 T^{* * * *}$ & $-\cdot / r \omega^{\text {券 }}$ & $-* / 1$ & وضعيت زناشويى \\
\hline 1 & 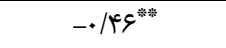 &.$/ 1 q^{\text {券䄅 }}$ & 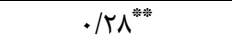 &.$/ 10$ & كيفيت زندكَى \\
\hline
\end{tabular}

زناشويى رابطه منفى معنادارى (كه/•-) در سطح I +/ دارد به اين معنى كه افرادى كه كمتر در زندگىشان در جست و جـوى معنا هستند بيشتر دجار مشكلات زناشويى هستند كه البته ايـن رابطه از نوع همبستخى است و نمى توان در مورد علت و معلـول بودن هيج كدام نظرى داد. نتايج همجنين حاكى از آن است كـهـ حضور معنا در زندگى با وضعيت زناشـويى همبسـتخى متوسـط

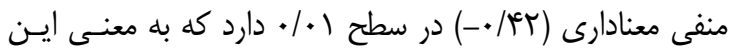
است كه افرادى كه معناى كمترى را در زنـدكى شـان احسـاس مى كنند از لحاظ زناشويى وضعيت نامساعدترى دارند. به همـين
همان طور كه نتايج جدول fا نشان مىدهد بين متغيرهاى منبـع كنترل، معناى زندگى و وضعيت زناشويى با كيفيت زندگى رابطه وجود دارد كه فرض ا را تاييد مىنمايد. منبـع كنتـرل رابطـهى ضعيفى با وضعيت زناشويى (•/ •-) و كيفيـت زنسدگى (ه|/•) نشـان داد. بـين جسـت و جـوى معنـا باكيفيـت زنـدة يـى يـى

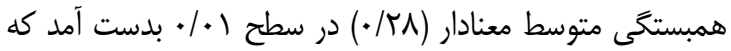
نشان مىدهـــ افـرادى كـهـ بيشـتر در جسـت و جـوى معنـا در زندگى شان هستند از كيفيت زنسـدَى بـالاترى نيـز برخوردارنـــ. نتايج همٍنين نشان مىدهد كه جست و جوى معنا با وضـعيت 


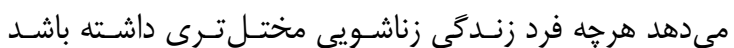
كيفيت زندكَ بايينترى نيز دارد.

براى بررسى امكان بيشبينى كيفيت زندگى توسـط متغيرهـاى منبع كنترل، معنـاى زنــدگى و وضـعيت زناشـويى از ركرسـيون جندگًانه به شيوه كَام به كام استفاده شد كه نتـايج در جـدول ه ارائه شده است.
ترتيب حضور معنا در زندگى با كيفيت زندگى همبسـتخى نسـبتا قوى مثبت و معنادارى (qء/•) در سـطح I • • دارد كـه نشـان مىدهد هرجه در زندگى فرد معناى بيشترى حضور داشته باشـد فرد كيفيت زندگى بالاترى نيز دارد و البته برعكس. و در نهايت اينكه وضعيت زناشويى با كيفيت زندگى همبستخى نسبتا قوى منفى و معنادارى (ع\&//•-) در سطح I • • نشان داد كـه نشـان

جدوله. تحليل ركَ سيون كام به كام براى پيشبينى كيفيت زندكى از طريق منبع كنترل، معناى زندكَى و وضعيت زناشويى

\begin{tabular}{|c|c|c|c|c|c|c|}
\hline Sig & & $\mathbf{F}$ & تعديل شده R2 & $\mathbf{R}^{2}$ & $\mathbf{R}$ & 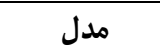 \\
\hline \multirow[t]{2}{*}{.$/ \cdots$} & & $M T / g V$ & $\cdot / \mu$ & $\cdot / \mu$ & .109 & r \\
\hline & \multicolumn{6}{|c|}{ ضرايب بتا و آزمون معنادارى t براى متغيرهاى ييشبين } \\
\hline Sig & $\mathrm{T}$ & Beta & STE & B & متغيرهاى يِيشبين & متغير ملاك \\
\hline.$/ \cdots$ & $4 / 99$ &.$/ \% \Delta$ &.$/ \cdot 4$ &.$/ 14$ & حضور معنا & \\
\hline \multicolumn{7}{|l|}{.$\ldots$} \\
\hline & $r / \cdot r$ & $-* / \mu \cdot$ & $.1+1$ & $\cdot / \cdot r$ & وضعيت زناشويى & بت زندَّى \\
\hline
\end{tabular}

ورود به معادله را نتوانست كسب كند (س人| • = Sig) و از معادلـه خارج شد. پِ از آن نيز متغير منبع كنترل وارد معادله رگرسيون شد كه آن نيز نتوانست شـرايط ورود بـه معادلـه را كسـب كنـــ ) و از معادله خارج شد. در نهايت اينكه حضور معنا با ضريب بتاى مثبت به صورت مثبت كيفيت زنـدگى را يـيشبينى مى كند (هس//Beta=) و وضـعيت زناشـويى كـه نمـرات بالاتر در آن بـهـ معنـى آشـفتخى و اخـتلال بيشـتر در رابطـهى زناشويى است با ضريب بتاى منفى بـهـ صـورت منفـى كيفيـت

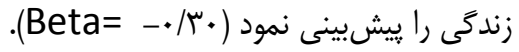

همانطور كه نتايج جدول ه نشان مىدهد متغيرهاى حضور معنـا در زندگى و وضعيت زناشويى توانستند به طور معنادار اس درصد از واريانس متغير وابسته يعنى كيفيت زندگى را ييشبينى نمايند.

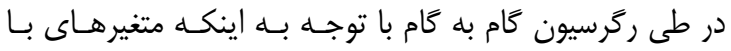
بالاترين همبستخى با متغير وابسته ابتدا وارد معادله مسىشـوند ابتدا متغير حضور معنا در زندگَى و سبس كيفيـت زناشـويى وارد معادله شدند كه شرايط ورود به معادله را كـه معنـادارى آمـارى درصد تبيين كنندگى در سطح ه+/ • بود، كسب كردند. در گَامهاى بعدى جست و جوى معنا وارد معادله شد كه حتـى شـرايط 


\section{بحث و نتيجه كَيرى}

يافته و بهتر مىتوانند با تجربه بازنشستخى كنـار بياينـد و حتى مى توانند بازنشستخى موفقى را تجربه نمايند.به طور كلى افـراد داراى منبع كنترل درونى از اعتماد به نفس، خودكارآمدى و توان حل مسئله بالاترى برخوردارند و اين امر باعث مىشود اين افراد از خود تصور مثبت ترى داشته باشند و از سوى ديگر ايـن افـراد احساس مى كنند مىتوانتـــــــر روى وقـايع محـيط يِير امونشـان كنتـرل داشـته باشـند و لــذا از سـلامت و سـازكًارى بيشـترى برخوردار بوده و به تبع كيفيت زندگى بـالاترى خواهنــد داشـت

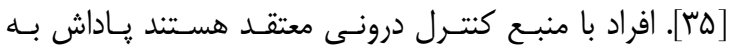
رفتارهاى آنها وابسته است، آنها در يـى كنترل سرنوشت خـويش هستند و در مقابل افرادى كه به كنترل بيرونسى گــرايش دارنـد، معتقدند كه وقايع زندكى تحت كنترل آنها نيسـت، بلكـه تحـت كنتـرل عوامـل و نيروهـاى خـارجى و بيرونـى اسـت [عس]. در ثروهش ديخرى تاييد شـد كـه افـراد بـا منبـع كنتـرل درونسى، سازگًارى روان شناختى بهترى را نشان مىدهند [YV]. در مطالعه باومستر (1991)، افراد زمانى معنا را در زندكى جستوجو كردهاند كه آنها معنا را در زندكَىشان ادراك نكردهاند يا زمانى كـه آنهـا رخداد استرسزايى را تجربه كردهاند. كـهـ ايـن مسـئله مسـتلزم سازگًارى جديد از طريق ييخيرى ساختارهاى معنايى جديد است

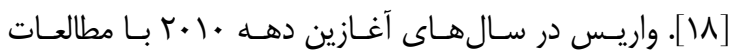
گَسترده، به مجموعه علائم و نشانههـايى رسـيده كـه آن را بــه عنوان نشانكان بازنشستخى مشتمل بـر مجموعـه نشـانههـايى شامل احسـاس بــه پايـان خـط رسـيدن، يـوجى و بـىمعنـايى، اضطراب، افسردگى و ترس از طرد شدن تعريف كرده است كـهـ

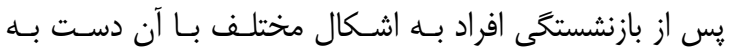
گريبان هستند [?T]. يس بر اين اساس وجود معنا و هدفمنـدى
يزوهش حاضر با هدف بررسى نقش منبع كنترل، معناى زندگى و روابط زناشويى در ييشبينى كيفيت زندكى بازنشستگان انجام شد. نتايج مطالعه نشان داد كـهـ بـين متغيرهـاى منبـع كنتـرل، معناى زندگى و وضعيت زناشويى با كيفيت زندگى رابطه وجـود دارد كه فرض ا را تاييد مىنمايد. منبع كنترل رابطهى ضـعيفى با كيفيت زندگى نشان داد. بين جست و جوى معنـا بـا كيفيـت زندگَى يك همبستخى متوسط معنادار بدست آمد كه نشان مىدهد افرادى كه بيشتر در جسـت و جـوى معنـا در زنـدگى شـان هستند از كيفيت زندكى بالاترى نيز برخوردارند. به همين ترتيب حضور معنا در زندگى با كيفيت زندگى همبسـتخى نسـبتا قوى مثبت و معنادارى دارد كه نشان مىدهد هرجـه در زنـدگى فـرد معناى بيشترى حضور داشته باشد فرد كيفيت زنسدگى بـالاترى نيز دارد و البته برعكس. و در نهايت اينكه وضعيت زناشويى بـا كيفيت زندگًى همبستخى نسبتا قوى منفى و معنادارى نشان داد كه نشان مى دهد هرجه فرد زندگى زناشويى مختلتـرى داشـته باشد كيفيت زندگى يايينترى نيز دارد. اين يافتـهــا همسـو بـاــا

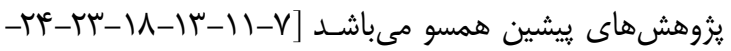

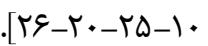
در تبيين يافتههاى حاضر مىتوان جنين اذعان داشت كه اصولاً بازنشستخى به دليل ييامدهايى كه دارد مسىتوانــد باعـث ايجـاد تغييراتى در زندگى افراد شود و در نتيجه كيفيت زنســى آنهـا را كاهش دهد. به همين دليل اخر بازنشستخان در دوره كنارهگيرى

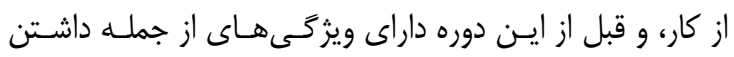
مكان كنترل درونى و احساس كنترل بر امـور زنـدگى را داشـته باشند و در زندگى هدفمند باشند و همجنـين رضـايت زناشـويى خوبى را در طول زندگى تجربه نمايند، كيفيت زندگى آنها بهبود 
صورت منفى كيفيت زندگى را ييشبينى نمود. اما براساس نتايج تحليل رگرسيون كَام به كام، منبع كنترل و جست و جوى معنـا به دليل ضريب بتاى پايين نتوانستند شرايط ورود بــه معادلـه را كسب كند و از معادله خارج شدند. اين يافتهها همسو بــا يافتـهـ-

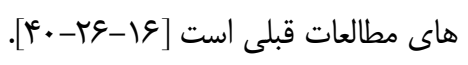

در تبيين اين يافتهها مىتوان جنين اذعان داشت كـه معنـادارى در زندگى و وضعيت زناشويى خوب بهترين ييشبينى كنندهاى كيفيت زندگَى در بازنشستشان محسوب مىشوند كه با اطمينـان بيشترى مىتوانند سازگًارى با بازنشستخى را بيشبينـى نماينـد. لذا بر اين اساس افراد مىتوانند با خلق معنـا در زنـدكى خـود و هدفدار كردن زنـدكى در تمـام طـول عمـر و بـهـ ويـزَه بعـد از بازنشستخىى، سازكًارى بيشترى با زنـدكى را تجربـهـ نمـوده و از سوى ديخر بـا بـالا بـردن كيفيـت روابـط زناشـويى خـود ايـن سازگًارى را بيشتر و يررنگتر نمايند.

معناى زندگى در اصل ماهيت شناختى دارد زيـرا در بركيرنـدهى باورهاى افراد در مورد وجود يك هدف غايى در زندگى، اعتقـاد به معنويات و زندكَى اخـروى اسـت و در واقـع داشـتن معنـا در زندگى، يكى از ييشبينى كنندههاى رفـاه و رضـايت از زنـدگى است [ أf]. فرانكل معتقد است كه اخر افـراد معنـايى را تعقيـب نكنند و هدفى را نداشته باشند احتمالا به هر بيراههاى منحـرف خواهند شد خرا كه انسان هدفمند بـدون توجـهـ بـه مسـيرهاى انحرافى جهت زندكَى خود را تعيسين مسىكنـد، تعـالى نفس را تجربه مى كند و با رضايت و آرامش روانى از زندگى خود بهـرهمند مى گردد و سازگًاى بهترى با تغييرات زندگى خواهد داشت [F]. همجنين بهبود روابط زناشويى هم مسىتوانسـ بـر كيفيـت زندگى بازنشستخان تاثير گذارد. نتايج مطالعه يناغى و همكـاران نشان داد كه روابط خانوادگى و زناشويى مىتواند كيفيت زندگى
در زندگى هم مى تواند بر وضعيت بازنشستخان و كيفيت زنسدىى أنها تاثير داشته باشد و اين مسئله در يزوهش حاضر مورد تاييـد

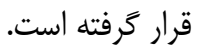

در ارتبـاط بـا رابطـهـه وضـعيت زناشـويى بــا كيفيـت زنسـدَى در بازنشستخان مطالعات نشان داده است كـهـ افـراد بازنشسـته بــه دليل ترك شغل و حضور بيشتر در منـزل و در بـين خـانواده در صورتى كه از حمايت خانوادگى و رضايت زناشويى خوبى بهرهمند باشد مىتواند تجربه خوبى از بازنشستخى را داشته باشد. در مطالعه انجمنيان در مورد مقايسه كيفيت زندگى كلى به تفكيك وضعيت تاهل نشان مىدهد كه بين كيفيت زندگى افراد مجـرد، متاهل و مطلقه ارتباط معنى دار آمارى وجود دارد، به طورى كـهـ ميانگَين امتياز كيفيت زندگى افراد مطلقه از افراد متاهل و مجرد

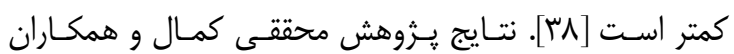

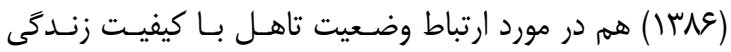
بازنشستخان نشان داد كه ارتباط معنادارى بين آنها وجود دارد به طورى كه ميانخَين امتياز كيفيت زندگى افراد همسر فـوت شـده از افراد متاهل كمتر است كه نشـاندهنــده تـاثير حمايـتهــاى خانوادگى و زناشويى از بازنشستكان و تاثير آن بر كيفيت زندگى آنان است [R [R]. عابدى هم در يزوهش خود نشان داد كـه بـين ميانگَين امتيازات كيفيت زندگى با وضعيت تاهل رابطـه معنـــ دارى وجود دارد به گَونهاى كه افرادى كه همسر آنها فوت شده داراى كيفيت زندگى هايينترى نسبت به كسانى كه همسر آنهـا در قيد حيات بود، داشتند [qج]. يافته بعدى يزوهش نشان داد كه حضور معنـا بـا ضــريب بتـاى مثبت به صورت مثبت كيفيت زندگى را هـيشبينسى مسى كنــ و وضعيت زناشويى كه نمرات بالاتر در آن بـه معنـى آشـفتخى و اختلال بيشتر در رابطهى زناشويى است با ضريب بتاى منفى به 
ضمن لذت بردن از اين تجربه، كيفيـت زنـــى بهتـرى داشـته

باشند.

$$
\text { تشكر و قدردانى }
$$

ايـن يـروهش در قالـب فعاليتهـاى هسـته يزوهشـى مطالعـات

سالمندى كه مورد تصويب معاونـت يُوهشى دانشـعاه علامـهـ

طباطبائى است، انجام شده است. بـــين وسـيله يزوهشـحَران از

تمام كسانى كه در اين بزوهش مشاركت و همكارى داشتند بــهـ

ويثه بازنشستًان شهرستان نهاوند، سياسگزارى مىنمايند.
سالمندان را يِيشبينى كند و يكى از مهمترين عوامل تاثيركَذار

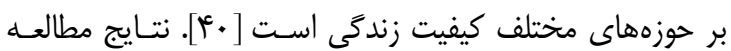
برزكر و سامانى هم نشان داد كه كيفيت زندَى افراد تحت تاثير مستقيه و غيرمستقيم الكوهاى ارتباطى و روابط زناشويى زوجين است و لذا رضايت زناشويى بهينه هم مىتواند بر كيفيت زندكى بازنشستخان تاثير كذارد [سع]. از محدوديتهاى يزوهش حاضـر مى توان به روش يخوهش اشاره كرد كـه امكـان تعيـين روابـط علت و معلولى بين متغيرهاى مسـتقل و وابسـته هـروهش را بـاــا محدوديت مواجه مى كند. بنابراين به يزوهشكَران آتى ييشـنهاد مىشود تا با روش هاى بزوهشى ديخـــى از جملـه روشهـاى مقطعى و طولى به بررسى اين روابط على بيردازنـــ. همجنــين تمامى سازمانها و اركانهاى دولتى و غيردولتى مـىتوانـــد بـاــا بركزارى دورههايى به صورت كاركَاه و كـلاسهـاى آموزشىى، ضمن آموزش مسائل مرتبط با بازنشستخى به عنوان تغييرى در زندگى كليه افراد شاغل، به آمـوزش احسـاس كنتـرل و تسـلط بيشتر در زندگى، معنا دادن به زندگى و بهبـود روابـط زناشـويى بيردازند تا افراد بتوانند با تجربه خوشايندترى بازنشسـته شـده و

\section{- References}

1. Topa G, Moriano JA, Depolo M, Alcover CM, \& Morales JF. Antecedents and consequences of retirement planning and decision-making: A meta-analysis and model. $\mathbf{J}$ Vocat Behav 2009; 75(1): 38-55.

2. Hesketh B, Griffin B, \& Loh V. A future-oriented retirement transition adjustment framework. J Vocat Behav 2011; 79(2): 303-314.

3. Froidevaux A, Hirschi A, \& Wang M. The role of mattering as an overlooked key challenge in retirement planning and adjustment. J Vocat Behav 2016; 94: 57-69.

4. Fassino S, Leombruni P, Daga GA, Brustolin A, Rovera GG, \& Fabris F. Quality of life in dependent older adults living at home. Arch Gerontol Geriatr 2002; 35(1): 9-20. 
5. Zandipour T. Attitude of patients with MS compared to their quality of life and psychological counseling. Psychol Stud 2010; 5 (2): 89-116. (persian).

6. Malek M, Hassankhani H, Darwishpour kakheki A, Asghari Jafar Abadi M, Mansouri Arani MR, \& Mohammad Nejad S. Quality of life and its relationship with personal characteristics, social, economic and health Tabriz city retirees. J Nurs Res 2017; 11(1):34-41. (persian).

7. Abeles RP. Sense of control, quality of life, and frail older people. The concept and measurement of quality of life in the frail elderly 1991; 297-314.

8. Molaee A, Yazdan bakhsh K, \& Karami J. The relationship between five factor model of personality and Locus of Control with job compatibility in staff gas company Kermanshah. J Pers Individ Differ 2015; 3(4):107-121. (persian).

9. Ashoori J. The relationship personality traits, religious orientation and locus of control with marital satisfaction in elderly women. J Geriatr Nurs 2016; 1(3):21-33. (persian).

10. Heidari tafreshi GH. Structural equation modeling approach in explaining the relationship between attachment style and locus of control and marital satisfaction, the faculty members of Islamic Azad University Roodehen Branch. J Educ Manag 2013; 3(3):23-44. (persian).

11. Gueritault-Chalvin V, Kalichman SC, Demi A, \& Peterson JL. Work-related stress and occupational burnout in AIDS caregivers: test of a coping model with nurses providing AIDS care. AIDS care 2000; 12(2):149-161.

12. Cohen K, \& Cairns D. Is searching for meaning in life associated with reduced subjective well-being? Confirmation and possible moderators. J Happiness Stud 2012; 13(2):313331.

13. Damásio BF, Koller SH, \& Schnell T. Sources of Meaning and Meaning in Life Questionnaire (SoMe): Psychometric properties and sociodemographic findings in a large Brazilian Sample. Acta de Investigación Psicológica 2013; 3(3):1205-1227.

14. Schnell T. The Sources of Meaning and Meaning in Life Questionnaire (SoMe): Relations to demographics and well-being. J Posit Psychol 2009; 4(6):483-499. 
15. Rathi N, \& Rastogi R. Meaning in life and psychological well-being in pre-adolescents and adolescents. J Indian Acad Appl Psychol 2007; 33(1):31-38.

16. Korte J, Cappeliez P, Bohlmeijer ET, \& Westerhof GJ. Meaning in life and mastery mediate the relationship of negative reminiscence with psychological distress among older adults with mild to moderate depressive symptoms. Eur J Ageing 2012; 9(4):343-351.

17. Van Ranst N, Marcoen A. Structural components of personal meaning in life and their relationship with death attitudes and coping mechanisms in late adulthood. na; 2000.

18. Damásio BF, Koller SH. Meaning in Life Questionnaire: Adaptation process and psychometric properties of the Brazilian version. Revista Latinoamericana de Psicología 2015;47(3):185-95.

19. Farghadani A, Navabinejad Sh, \& Shafiabadi A. Design a causal model based on full attention and presence of mind, lack of existential resistance in the face of life and society with a focus on Search for meaning in life. J Res Women 2010; 3(1):112-129. (persian).

20. Sudani M, Dehghani M, \& Dehghanzadeh Z. The effectiveness of transactional analysis (TA) on matrimonial boredom and quality of life of couples. J Couns Fam Ther 2014; 3(2):159-181. (persian).

21. Trudel G, Dargis L, Villeneuve L, Cadieux J, Boyer R, Préville M. Marital, sexual and psychological functioning of older couples living at home: The results of a national survey using longitudinal methodology (part one). Sexol 2013;22(4):e101-7.

22. Gong M. Does status inconsistency matter for marital quality?. J Fam Issues 2007;28(12):1582-610.

23. DeLamater J, Hyde JS, Fong MC. Sexual satisfaction in the seventh decade of life. J Sex Marital Ther 2008;34(5):439-54.

24. Trudel G, Turgeon L, Piché L. Sexual and marital aspects of old age. Sex Relationsh Ther 2010;15:381-406.

25. Hosseini AM, Rasoli M, Davarniya R, Babaie Garmekhani M. Effectiveness of Group Based on the practical application of intimate relationship skills on the quality of the marital relationship. J Med Sci 2017;24(2):8-17. (persian). 
26. Rahimi M, Khaier M. The relationship of family communication patterns and quality of life in Shiraz high school students. Stud Educ Psychol 2010;10(1):5-25. (persian).

27. Biabangard I. Research methods in Psychology and Educational Sciences. Volume 1, Tehran: Doran; 2013. (persian).

28. Mohagheghi Kamal SM, sajadi H, Zare H, Biglarian A. Compare the quality of life of elderly pensioner Social Security Organization and National Retirement living in the city of Qom, 2008. J Health Adm 2008; 10(27):49-56. (persian).

29. Salimi E, Dasht Bozorgi B, Mozafari M, Tabesh H. Investigating mental health status and life satisfaction of retired elderly referred to retirement's centers of the Jundishapur University of medical sciences and shahid Chamran University in Ahvaz. Iranian J Geriatr Nurs 2014;1(1):20-31. (persian).

30. Fayaz I, Kazemi S, Raysion MR, Mohammadi Y. The relationship learning motivation belief and dimensions of locus of control with academic achievement of students. Res Med Educ 2017;8(2):69-76. (persian).

31. Nasiri M, Karsazi H, Ismail Pour F, Bayrami M. The effect Meaning in life,, mindfulness and resilience in students flourish. J Posit Psychol 2016; 1(3):21-32. (persian).

32. Isa nejad $\mathrm{O}$, Ahmadi SA, Atemadi E. The impact of attachment on mental health. Proceedings of the Third National Congress of Family Pathology; 2009:p 292. (persian).

33. Saifuddini Banadkoki A. [Investigate the relationship between differentiation and marital quality in universities in Yazd married staff members]. Master's thesis, Allameh Tabataba'i University 2013. (persian).

34. Nejat S, Montazeri A, Holakouee K, Kazem M, Majdzadeh R. The standardization of the World Health Organization Quality of Life Questionnaire; translation and Psychometrics Iranian version. J Sch Health Inst Health Res 2007; 4:1-12. (persian).

35. Safarian MR, Ashoori J. Examine the relationship between locus of control, personality traits, self-esteem and religious orientation with the desired behavior discipline. $\mathrm{J}$ Ment Health 2015; 16(3):476-83. (persian).

36. Kee Tony TS. Locus of control, attributional style and discipline problems in secondary schools. Early Child Dev Care 2003; 173(5):455-466. 
37. Harris C, Linda O, Pamela M. Situation and Personality correlates of psychological WellBeing: Social Activity and personal, Control; 2002.

38. Anjmnyan V. The Influence of continuous care model on quality of life in schizophrenic patients discharged from hospital in Hamedan. Tehran: University of Social Welfare and Rehabilitation Sciences; 2005. (persian).

39. Abedi HA. Comparison of quality of life of elderly people living at home and in nursing homes in Isfahan. Research project, Isfahan University of Medical Sciences; 2000. (persian).

40. Panaghi L, Abaresh Z, Mansouri N, Dehghani M. Quality of life and demographic characteristics associated with the elderly in Tehran. Iranian J Ageing 2010; 4(12):77-87. (persian).

41. Ho MY, Cheung FM, Cheung SF. The role of meaning in life and optimism in promoting well-being. Pers individ differ 2010;48(5):658-63.

42. Maliki K. The relationship between coping strategies with the meaning of life and happiness among students of Tabriz University. Master's thesis, University of Tabriz; 2008. (persian).

43. Barzegar I, Samani S. The mediating role of intimacy in the relationship between communication patterns and marital life. J Women Soc 2017;7(2):115-128. (persian). 